\title{
Coexistence of Touraine-Solente-Gole syndrome and type 1 neurofibromatosis: A case report
}

\begin{abstract}
Pachydermoperiostosis is a rare syndrome that affects the skin and skeletal system. Mutations in the gene encoding hydroxyprostaglandin dehydrogenase (HPGD) are thought to play a role in disease etiopathogenesis. The disease is typically seen in males and is characterized by skin thickening (pachydermia), clubbing, and subperiosteal new bone formation. A 57-year-old male patient was admitted to our clinic with growth complaints of growth his hands, feet, and face. He had a prominence of forehead lines and fist-sized round bulges on his torso and face. The patient's history also indicated that he was clinically followed up for neurofibromatosis 1 (NF1). No mutations in the HPGD and SLCO2A1 genes were identified. This is the first case in the literature that reviews pachydermoperiostosis and NF together. The coexistence of skin findings of two different diseases in the same patient indicates that both diseases may be related to different genetic pathways.

Keywords: Neurofibromatosis, pachydermoperiostosis, cutis verticis gyrata
\end{abstract}

Öz

Pakidermoperiostoz iskelet sistemi ve deriyi etkileyebilen genetik geçişli nadir görülen bir hastalıktır. Hastalığın etiyopatogenezinde, hidroksiprostaglandin dehidrogenazı (HPGD) kodlayan gende mutasyonların rolü olduğu düşünülmektedir. Hastalık daha çok erkeklerde görülmekte ve deride kalınlaşma (pachydermia), çomak parmak, subperiostal yeni kemik oluşumu gibi klinik bulgularla seyretmektedir. Elli yedi yaşında erkek hasta el, ayaklarda ve yüzde büyüme, alın çizgilerinde belirginleşme, gövde ve yüzde ele gelen yuvarlak kabarıklıklar şikayeti ile kliniğimize başvurdu. Aynı zamanda hastanın nörofibromatöz 1 (NF1) nedeniyle tanı aldığı ve takipte olduğu öğrenildi. Yapılan analizde, HPGD ve SLCO2A 1 genlerinde mutasyon görülmedi. Bu olgu NF ve pakidermoperiostoz birlikteliğinin görüldüğü nadir bir olgudur. Bu iki farklı hastalığın aynı hastada bir arada bulunması, bir genetik mutasyonun veya diğer altta yatan faktörlerin her iki durumun varlığından sorumlu olabileceğini düşündürmektedir.

Anahtar Kelimeler: Nörofibromatozis, pakidermoperiostozis, kutis vertisis girata

\section{Introduction}

Pachydermoperiostosis (Touraine-Solente-Gole syndrome,

OMIM number 259100) is a rare syndrome defined by
Friedrich in 1868 that affects the skin and skeletal system. The disease is primarily transmitted in an autosomal dominant manner, although autosomal recessive, X-linked, and sporadic cases have been reported ${ }^{1,2}$. Mutations in

Address for Correspondence/Yazışma Adresi: Selma Korkmaz MD, Süleyman Demirel University Faculty of Medicine, Department of Dermatology, Isparta, Turkey Phone: +90 5063567227 E-mail: selmakorkmaz35@gmail.com Received/Geliş Tarihi: 29.07.2020 Accepted/Kabul Tarihi: 11.03.2021 ORCID: orcid.org/0000-0003-3877-3976

Cite this article as: Korkmaz S, Korkmaz H, Erturan I, Ayvaz Çelik HH, Hekimler Öztürk K, Yıldırım M. Coexistence of Touraine-Solente-Gole syndrome and type 1 neurofibromatosis: A case report. Turkderm-Turk Arch Dermatol Venereol 2021;55:143-6.

(C) Copyright 2021 by Turkish Society of Dermatology and Venereology

Turkderm - Turkish Archives of Dermatology and Venereology published by Galenos Yayınevi. 
the gene encoding hydroxyprostaglandin dehydrogenase (HPGD) are thought to play a role in the etiopathogenesis ${ }^{2-4}$. The disease is typically observed in males and characterized by skin thickening (pachydermia), clubbing, and subperiosteal new bone formation ${ }^{5,6}$.

Neurofibromatosis type-1 (NF1) was first described in 1882. This is a rare hereditary disease characterized by multiple café-au-lait spots, neurofibromas, and skeletal changes. Skeletal defects in NF1 are secondary to anomalies in neuroectodermal and mesodermal tissues ${ }^{7}$. For the diagnosis of NF1, the presence of NF in a first-degree relative, presence of six or more café-au-lait spots (greater than $0.5 \mathrm{~cm}$ in children, and greater than $1.5 \mathrm{~cm}$ in adults), freckling in the axillary region or groin, lisch nodules in the iris and optical glioma, neurofibromas (two or more), and bone anomalies (thinning of the cortex in long bones and dysplasia in the wing region of the sphenoid bone) $)^{8}$. Here, a case with both NF1 and pachydermoperiostosis is presented.

\section{Case Report}

A 57-year-old male patient was admitted to our clinic with complaints of growth of his hands, feet, and face. He had a prominence of forehead lines and fist-sized round bulges on his torso and face. The patient stated that these complaints have existed since childhood. He said that occasionally he had bone pain. The patient's history indicated surgery due to urethral stricture, the presence of benign prostatic hypertrophy, and carpal tunnel syndrome. He had been treated for tuberculosis three years ago. He also indicated that he was clinically followed up for NF. His family history was unremarkable. On physical examination, the patient was conscious, cooperative, and his cardiovascular system and abdominal examination were normal. The patient did not report any respiratory problems. His dermatological examination revealed coarsening, and he had an oily appearance of his face and hair, a prominence of lines on his forehead and frontal region, thickening and growth on his hands and feet, white-yellow papular lesions with multiple adenoid-like appearances on his face. He also had variable nodules with multiple sizes on his trunk, bilateral axillary freckles, dark-colored macules in the axilla, multiple café-au-lait spots on his arms and back, and multiple hypopigmented macules on the anterior and posterior side of his trunk (Figure 1-3). His laboratory tests indicated that his hemogram, liver, and kidney function tests, vitamin B12 level, C-reactive protein, and sedimentation rate were normal. In addition, his antinuclear antibody, venereal disease research laboratory, hepatitis markers, fecal occult blood test were negative, and a peripheral blood smear was normal. An examination of his hormone

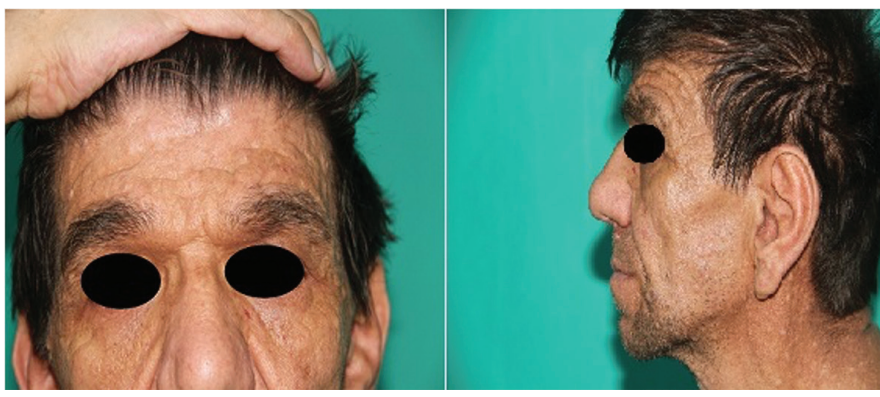

Figure 1. The coarsening and oily appearance of the face and hair, prominence of a sulcus on the forehead and frontal region profile indicated normal levels of thyroid-stimulating hormone, cortisol, prolactin, and adrenocorticotropic hormone. Acromegaly was ruled out since his insulin-like growth factor-1 (IGF-1) levels were normal in accordance with his age and sex. Also, his growth hormone (GH) levels were suppressed by $75 \mathrm{mg}$ glucose in an oral glucose tolerance test (OGTT). On radiologic examinations, bronchovascular branching and mild mediastinal enlargement was observed in his chest and, periosteal reaction and bilateral cortical thickening of the humerus diaphysis were seen. Cortical thickening was also observed in his metacarpals and proximal phalanges. Computerized tomography of the thorax showed ground glass densities in the lower lobe of the left lung. There was no active infiltrative lesion in the right lung parenchyma. Magnetic resonance imaging (MRI) of the brain and pituitary gland was normal. The patient was referred to the chest diseases department because of the findings in his lung, and follow-up suggested that the findings might be associated with the patient's history of tuberculosis. Acromegaly was not considered, since the endocrinologic evaluation of the patient

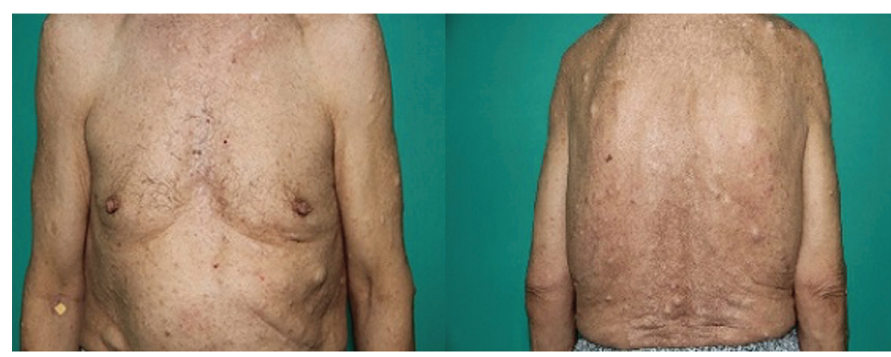

Figure 2. Variable nodules in multiple sizes on the trunk

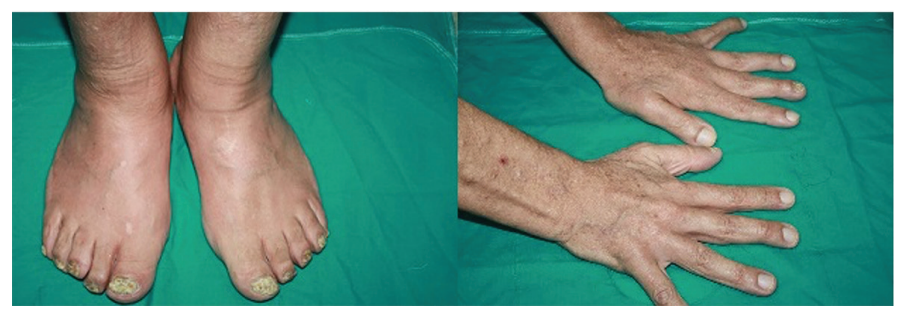

Figure 3. Thickening and growth in the hands and feet
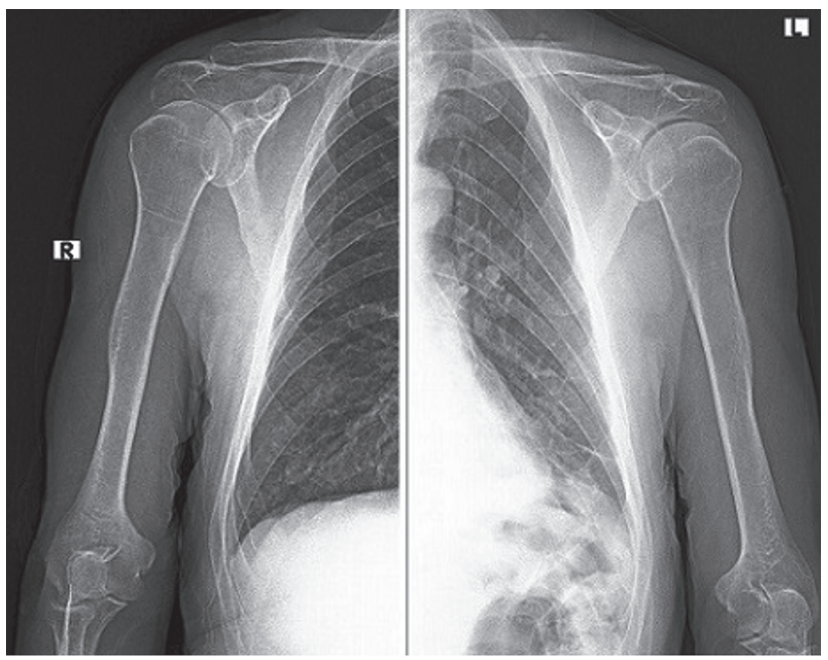

Figure 4. The periosteal reaction and bilateral cortical thickening of the humerus diaphysis 
was normal. An excisional biopsy obtained from the nodular lesion in the arm indicated the presence of neurofibroma. A punch biopsy from the hypopigmented area on the right anterior arm showed postinflammatory hypopigmentation. A left lung lower lobe tru-cut biopsy indicated focally active chronic inflammatory lung tissue. Mutation analysis of HPGD and SLCO2A1, in this case, was performed with nextgeneration sequencing. No mutations in HPGD and SLCO2A 1 genes were identified. Based on these findings, the patient was diagnosed with a complete form of pachydermoperiostosis and enrolled for clinical monitoring.

\section{Discussion}

Clinical signs of pachydermoperiostosis usually start in adolescence and can persist for 5-20 years. Although clinical findings vary according to the patient, pachydermoperiostosis is usually characterized by increased growth in the hands, feet, and face, bumping of the fingers, thickening and coarsening of the face and scalp, cutis verticis gyrata, cortical thickening of long bones, and new bone formation, ptosis, increased palmoplantar hyperhidrosis, glossy appearance of the face and scalp skin due to the increased activity of sebaceous glands 9 .

In addition, $40 \%$ of patients may have joint involvement with clinical findings, such as arthritis and arthralgia ${ }^{2,3,6,10-12}$. The disease has two subforms, primary and secondary. The secondary form can be associated with lung cancer, pulmonary diseases, heart diseases, inflammatory bowel diseases, hepatic cirrhosis, and various malignancies ${ }^{5,13}$. The primary form has three clinical subtypes, including a complete form with the skin and skeletal system involvement, an incomplete form without skin findings, and a fruste form with skin findings and minimal skeletal changes ${ }^{10}$. Complications, such as ptosis, nerve compression, hearing problems, kyphosis, arthrosis, and carpal tunnel syndrome, may develop in severe clinical cases.

Diagnosis of the disease is made by at least two positive findings, including the presence of family history, finger clubbing, hypertrophic skin changes, bone pain, and radiological findings (subperiosteal ossification of hands, feet, and long bones) ${ }^{14}$. The current case had bone pain, changes in bone structure, and hypertrophic changes in the skin. Radiologic examination of the patient revealed cortical thickening of the metatarsals, proximal phalanges, and the bilateral humeral diaphysis (Figure 4). In addition, the history of carpal tunnel syndrome suggested that this condition could be due to pachydermoperiostosis. Acromegaly and acral changes due to thyroid diseases should be considered in the differential diagnosis. No endocrinological abnormality was detected in our case. Acromegaly was eliminated because of the complete $\mathrm{GH}$ response to $75 \mathrm{mg}$ of OGTT and normal levels in the hormone profile. This case was considered a complete form of pachydermoperiostosis because of the involvement of the bone and skin. This case also presented with café-au-lait spots, multiple neurofibromas, and axillary freckling. There were no detected mutations in the HPGD and SLCO2A1 genes. The coexistence of skin findings of two different diseases in the same patient indicates that both diseases may be related to different genetic pathways.

In the literature, the coexistence of NF and acromegaly was reported. However, somatotroph adenoma was shown, and increased $\mathrm{GH}$ secretion was found in their case. In addition, an increase in $\mathrm{GH}$ levels with the $75 \mathrm{mg}$ OGTT test and the presence of a pituitary adenoma on
MRI were shown ${ }^{15}$. In the present case, the $\mathrm{GH}$ level was suppressed by the $75 \mathrm{mg}$ OGTT test, and the IGF-1 level was normal. Furthermore, the MRI of the brain and pituitary gland was normal. Therefore, the diagnosis of acromegaly was excluded.

It has been shown that local gigantism can be seen as a manifestation of NF. It is thought that osteochondromas of the phalanges are seen due to the influence of neural intrinsic factor of NF or basic intrinsic factor. Furthermore, these factors may cause soft tissue overgrowth, blood vessel wall thickening, and osteochondromas on the phalanges ${ }^{16}$. The present case was evaluated as pachydermoperiostosis because of cutaneous findings, periosteal reaction, and bilateral cortical thickening of the humerus diaphysis, metacarpals, and proximal phalanges. There was no identified secondary cause in the present case. Therefore, pachydermoperiostosis was considered as the complete form. However, as mentioned above, these cutaneous findings, considered pachydermoperiostosis, may be due to intrinsic factors associated with NF. This situation needs to be investigated better in the future.

There is no effective treatment for this disease. Non-steroidal antiinflammatory drugs and colchicine are help relieve the symptoms of arthritis and arthralgia ${ }^{10}$. There are cases in which retinoid therapy has been used to reduce collagen formation and lubrication for skin findings. Surgical treatments are also available for cosmetic purposes ${ }^{17-19}$. These types of cases require close clinical monitoring concerning clinical involvement that may accompany both diseases.

This study highlights the notion that skin findings should be evaluated carefully in patients presenting with symptoms, suggesting acromegaly. In addition, after more cases and studies of patients with both NF and pachydermoperiostosis have being reported, the possible underlying shared etiopathogenesis of these diseases should be investigated.

\section{Ethics}

Informed Consent: Informed consent form was obtained from the patient.

Peer-review: Externally peer-reviewed.

\section{Authorship Contributions}

Surgical and Medical Practices: S.K., H.K., K.H.Ö., Concept: S.K., H.K., H.H.A.Ç., I.E., M.Y., Design: S.K., H.K., H.H.A.Ç., I.E., M.Y., Data Collection or Processing: S.K., H.K., H.H.A.Ç., I.E., M.Y., Analysis or Interpretation: S.K., Literature Search: S.K., H.K., H.H.A.Ç., Writing: S.K. Conflict of Interest: No conflict of interest was declared by the authors.

Financial Disclosure: The authors declared that this study received no financial support.

\section{References}

1. Hong C, Devic N, Zavareh A, Desai A, Ng N: Pachydermoperiostosis: The Elephant Skin Disease. J Rheumatol. 2017:44:1680-1.

2. Kwon MY, Joung C: Pachydermoperiostosis Mimicking Acromegaly: A Case Report. Turk J Rheumatol 2012;27:132-5.

3. Zhang Q, Shen M, Yang B, Yu K: A complicated case of pachydermoperiostosis with spondyloarthritides: a case report. J Med Case Rep 2013;7:268.

4. Nakahigashi K, Otsuka A, Doi $H$, et al: Prostaglandin E2 increase in pachydermoperiostosis without 15-hydroprostaglandin dehydrogenase mutations. Acta Derm Venereol. 2013;93:118-9.

5. Mobini M, Akha O, Fakheri H, Majidi H, Fattahi S: Pachydermoperiostosis in a patient with Crohn's disease: Treatment and literature review. Iran J Med Sci 2018;43:81-5. 
6. Doshi D: Touraine-Solente-Gole syndrome. Orbit 2018;37:97-101.

7. Uchiyama $Y$, Sumi T, Marutani $K$, et al: Neurofibromatosis type 1 in the mandible. Ann Maxillofac Surg 2018;8:121-3.

8. Ferner RE, Gutmann DH: Neurofibromatosis type 1 (NF1): diagnosis and management. Handb Clin Neurol 2013;115:939-55.

9. Abdullah NRA, Jason WLC, Nasruddin AB: Pachydermoperiostosis: a rare mimicker of acromegaly. Endocrinol Diabetes Metab Case Rep 2017 Doi:10.1530/EDM-17-0029.

10. Shakya P, Pokhrel KN, Mlunde LB, Tan S, Ota E, Niizeki H: Effectiveness of nonsteroidal anti-inflammatory drugs among patients with primary hypertrophic osteoarthropathy: A systematic review. J Dermatol Sci 2018;90:21-6.

11. Gupta M, Lehl SS, Singh R, Sachdev A. Touraine-Solente-Gole' syndrome. BMJ Case Rep 2011;28:1-4.

12. Durusoy Ç, Dilek A, Lakadamyalı H, Akaya H, Seçkin D. Primary complete pachydermoperiostosis: A sporodic case. T Klin J Med Sci 2003;23:245-9.

13. Lowenthal MN, Tombak A, Lowenthal A: Secondary hypertrophic osteoarthropathy (HOA) mimicking primary HOA (pachydermoperiostitis or Touraine-Solente-Golé) syndrome. Isr Med Assoc J 2004;6:64.
14. Supradeeptha C, Shandilya SM, Vikram Reddy K, Satyaprasad J. Pachydermoperiostosis-a case report of complete form and literatüre review. J Clin Orthop Trauma 2014;5:27-32.

15. Hozumi K, Fukuoka H, Odake Y, et al: Acromegaly caused by a somatotroph adenoma in patient with neurofibromatosis type 1. Endocr J 2019;66:853-7.

16. Inglis K. Local gigantism (a manifestation of neurofibromatosis): its relation to general gigantism and to acromegaly; illustrating the influence of intrinsic factors in disease when development of the body is abnormal. Am J Pathol 1950;26:1059-83.

17. Athappan G, Unnikrishnan A, Chengat V, et al: Touraine Solente Gole syndrome: the disease and associated tongue fissuring. Rheumatol Int 2009;29:1091-3.

18. Seyhan T, Ozerdem OR, Aliagaoglu C: Severe complete pachydermoperiostosis (Touraine-Solente-Golé syndrome). Dermatol Surg 2005;31:1465-7.

19. Prerna, Ghosh R, Barua JK, Das AK: Pachydermoperiostosis mimicking acromegaly: A case report. Indian Dermatol Online J 2018;9:182-4. 